properties of a liquid, and may be dealt with in a continuous process. Plants working on this principle which are in use or on order (excluding the U.S.S.R.) are capable of dealing with $60,000,000$ tons of feedstock per year.

In a discussion on the process of activation of montmorillonites, Dr. B. S. Emöli (Fullers' Earth Union, Ittd.) explained that, by means of acid treatment, the crystalline structure appears to be partly broken down. The improved catalytic activity may be associated with the presence of free colloidal silica, or with the greater effective surface of the mineral, or with both factors.

The afternoon session contained papers on topics connected with adsorption. It was opened by Mr. A. Ibison (W. Bibby and Sons, Ltd.), who dealt with the adsorption of colours from oils and solvents. $\mathrm{He}$ stressed the importance of fixed conditions of temperature, moisture, acidity, etc. Adsorption isotherms, corresponding to maximum percentage colour adsorbed at each colour concentration, are then found to be of the Langmuir type with non-activated clays, and steeper with the activated type.

Dr. G. W. Nederbragt (Bataavsch Petroleum Mij, Amsterdam) described the use of floridin for separating long-chain from branched-chain hydrocarbons. The technique used is essentially that of chromatographic analysis with pentane as the solvent. The author suggested that the selective adsorption of normal hydrocarbons is due to the channels present in the structure, as described by Bradley ${ }^{1}$.

Experiments on the adsorption of basic dyes by calcium montmorillonite were described by Dr. Emödi. It was observed that while the dye adsorbed is nearly equivalent to the base-exchange capacity of the clay (104 m. equiv. por $100 \mathrm{gm}$.), usually only 30-80 m. equiv. of calcium are released, the discrepancy increasing with the number of benzene rings in the molecule. From calculations of the frequency of calcium ions between the montmorillonite sheets and the area of the dye molecules, the theory was advanced that the latter are adsorbed between the unit plates, but mainly near the edges, thus blocking the outlet of many exchangeable calcium ions. The clay particles thus become positively charged and can adsorb negative ions.

Dr. D. M. C. MacEwan (Rothamsted Experimental Station) suggested that the mechanism of formation of organic complexes by montmorillonite may be closely connected with surface adsorption on such minerals as mica, the tendency of the clay mineral sheets to gather one or more adsorbed layers of molecules providing a repulsive force between them, while the balancing attractive force may be electrostatic in nature. Using Bangham's data ${ }^{2}$ on mica adsorption, it is possible to get a potential curve for methanol showing a minimum in the right position.

Two general papers, descriptive of work done under a programme of research for the British Iron and Steel Research Association, were given by Dr. J. White and collaborators of the University of Sheffield. The substance of the paper by B. Vassiliou has already appeared in Nature $^{3}$. The second (with P. Murray) dealt with an attempt to measure reaction constants and activation energies for the thermal dissociation of structural water in different types of clay, using both constant and steadily increasing heating rates. Good results were obtained with kaolinitic and micaceous clays enabling the form of thermal analysis peaks to be reproduced from the calculated data; but with a montmorillonitic clay the values obtained for the constants depended on the conditions of heating, a point which is now bəing investigated.

Comparison of the papers given in the morning and afternoon sessions suggested that phenomena of adsorption tend to bo better correlated with what is known of the clay mineral structures than those of catalysis. Meetings such as this should therefore serve a useful purpose by bringing together clay mineralogists with chemists working on the problem of catalysis, and enabling them to exchange information.

D. M. C. MacEwaN

${ }^{1}$ Bradley, W. F., Amer. Min., 25, 405 (1940).

2 Bangham, D. H., and Mosallam, S., Proc. Roy. Soc., A, 166, 558 (19:8).

${ }^{2}$ Vassiliou, B., and White, J., Nature, 181, 487 (1948).

\section{ELM DISEASE}

$\mathrm{E}^{\mathrm{L}}$ LM disease has been a serious pest in Britain during the last score of years. The Forestry Commission has issued Leaflet No. 19 (London: H.M. Stationery Office, 1947), which is an up-to-date account of what is known at present about this disease, the life-histories of the associated bark beetles, and control measures.

The attack in most parts of England and Wales is by now pretty well known, and the trees either die down from the top, or they may die from the top down one side. Usually the cause of the die. back is the fungus Ceratostomella ulmi Buism. working in association with Scolytus elm bark beetles. When this disease was first discussed, it was known as the Dutch elm disease, having come into Britain from, it was thought, Holland. Its connexion at that time with the bark beetle was not generally appreciated. The fungus is a member of the Ascomycetes. It exists in the tree mainly in the form of small yeast-like bodies, which multiply rapidly by budding, and are carried along in the water-conducting vessels with the sap. The fungus produces a toxic substance, which not only poisons the affected branch, but also stimulates the vessel walls to produce gum-containing bodies. These tend to block the vessels and thus lead to death from lack of water, as well as from direct poisoning.

As is well known, bark bəetles are espəcially dangerous to a tree when anything has occurred to stop or to lessen. the upward flow of sap. In the case of elm disease, when the sap flow becomes restricted, the well-known elm bark beetles, Scolytus scslytus (destructor) and Scolytus multistriatus, can make their breeding grounds in the bark with comparative ease. The grubs hatching from the eggs thus have a cam. bium layer, with a restricted flow of sap but sufficient to keep it fresh, upon which they feed.

The fungus can only produce its minute and delicate fructifications in very sheltered situations, such as under loosened bark or in the beetle galleries. The fructifications are of two kinds, black flask. shaped bodies (asci) and thin black stalks (coremia); both are about $1 \mathrm{~mm}$. in length, and both bear microscopic spores at the top in round drops of mucilage. Although they are visible to the naked eye when produced in mass, they are hard to find, and of little value, therefore, in early diagnosis.

Ceratostomella ulmi is not the only cause of disease in elnfs; but in the south of England, at any rate, it outweighs all other diseases in importance. In Scotland the wych elm is subject to a dieback less 
rapid and usually less severe than that caused by true elm disease; the cause is as yet unexplained. Elms in towns may be killed by gas leakages, and those in unfavourable situations are often injured by drought or excessive water in the soil; but these causes of death are easily distinguished from the elm disease proper.

Bull. 841, Cornell University Agricultural Experiment Station (September 1947) also deals with elm disease; it is entitled "Log Treatments for Bark Beetle Control in connection with the Dutch Elm Disease". The bulletin is devoted to the assembly of the principal data from a series of long-treatment experiments carried out at the Dutch elm disease research laboratory of the New York State College of Agriculture. The War stopped a number of the experiments which were in hand, and others which had been planned were not begun. It was therefore decided to publish all the results of the work so far carried on, so that this information might be available for the continuation of research, and the determ. ination of control programmes.

The fungus is the same as that mentioned above, but the beetles working in conjunction with the fungus in the United States are Scolytus multistriatus and Hylurgopinus rufipes. The disease organism is described as harbouring in bark beetle galleries made in wood from healthy trees, as well as from diseased trees, and is carried out and distributed by the beetles which emerge. The proper disposal of dead and dying elm wood which is suitable for bark beetle breeding, even if it is not from diseased trees, is therefore an essential feature of a local Dutch elm disease programme.

It is not possible to deal more closely with the contents of this most interesting bulletin, which is well worth studying, with its interesting illustrations. It is, however, a matter of considerable interest that the so-called Dutch elm disease has now become very widespread, and it certainly requires intensive investigation. The present writer has himself been watching infested trees of his own during the past twenty years, and as one outcome of the observations carried out, considers it does not follow that a tree attacked will die, for it may throw off the disease. In this there is possibly some connexion between the vigorous state of the tree, and the fact that the Scolytus beetles do not get the upper hand; in fact, quite possibly they are unable to make their breeding galleries, owing to the flow of sap being too strong.

E. P. Stebbing

\section{NATIONAL INSTITUTE OF ECONOMIC AND SOCIAL RESEARCH}

$\mathrm{T}$

HE annual report of the National Institute of Economic and Social Research for 1946-47 records no change in the financial situation; grants from the Rockefeller Foundation, the Leverhulme Trustees and the Nuffield Foundation continuing to be the mainstay of the Institute's finances, and a special grant of $£ 1,000$ was made by the Nuffield Foundation for the support of a book to be published under the title "Lessons of the British War Economy", which is intended to form a professional symposium on British war economics. With funds of the Garton Foundation, transferred to the Institute in 1942, it has been decided to establish an annual Garton Prize, probably of the value of 100 guineas, which was to be offered for competition in 1948. It is intended to publish the prize-winning essay in a special Garton Monograph Series. Experience with the Senior Research Fellowship scheme which terminated during the year showed the value of the scheme in assisting university research during the transition period; but the increased funds becoming available for research in the sccial sciences in the universities of Great Britain have diminished the need for special awards for experienced research workers, and there is already difficulty in finding persons of sufficient maturity and experience for the programmes planned.

A grant was made to Bedford College in support of the research project entitled "An Enquiry into the Social Factors Determining Earned Income" being carried out by Mrs. Barbara Wootton, another to the Department of Applied Economics, University of Cambridge, for a senior research worker for the output section of the inquiry into expenditure, output and income, 1920-38, and another to pro. vide Prof. E. Victor Morgan, at University College, Swansea, with part-time research assistance for the project "Studies in British Financial Policy, 1914-25". It was expected that the report of the Joint Advisory Sub-Committee with the Institute of Chartered Accountants on the meanings and uses of terms commonly employed by both accountants and economists would be ready for submission to the Joint Exploratory Committee early in 1948. The Institute has also agreed to co-operate in the provision of bibliographical service with the International Association for Research in Income and Wealth.

The fourth issue of the "Register of Research in the Social Sciences" was circulated in the spring of 1947 , and the "Register" is in future to be published as an annual available on a subscription basis only. In regard to research programmes, the major task of fact-collecting for the "Distribution Enquiry" has been completed, and work on each of the three main parts of the "Building Enquiry" progressed steadily. Work has continued on the "National Expenditure, Output and Income, 1920-38, Enquiry", and a new investigation, to be called "The Social Accounts of Local Authorities", has developed out of work on the Public Authority section. The report on international comparisons of productivity in British and American manufacturing industry has been circulated privately to a limited number of research centres, Government departments and other organisations.

The contribution of the independent research institute is discussed at some length in the report, which points out that such organisations are the natural complement of the universities, with which, and Government departments, the report of the Clapham Committee was solely concerned. They can undertake investigations which are unlikely to be developed under university conditions, and apart from providing a common meeting-place for representatives of different interests and different approaches to the social sciences, they can take risks in opening new ground or trying expensive new methods which an individual scholar or university might not be able to afford. Among the ancillary functions of the independent research institute, special emphasis is laid upon that of providing a clearing house for information.

The Institute in March 1947 called an informal conference of some forty persons responsible for the conduct or organisation of research. As a result of 